\title{
Meningkatkan Kemampuan Siswa dalam Membaca Teks dengan Menggunakan Metode Reading Aloud di Kelas III SDN. No. 028/XI Tanjung Tahun 2017/2018
}

\author{
Hardianto ${ }^{1}$ \\ ${ }^{1}$ Guru SDN. No. 028/XI Tanjung, Kecamatan Hamparan Rawang, Kota Sungai Penuh, Provinsi Jambi \\ e-mail: hardianto.h19@gmail.com
}

\begin{abstract}
This study aims to improve the ability of students to read texts by using aloud reading methods in class III SDN. No. 028 / XI Tanjung in 2017/2018. The research conducted was classroom action research conducted at SDN. No. 028/XI Tanjung. This research was conducted from July to November 2017. The study involved 15 third grade students. Classroom action research was conducted in two cycles (Cycle I and Cycle II) and each cycle consisted of two meetings with four activities namely planning, implementation, observation, and reflection. Data was collected by test and observation techniques. Furthermore, the data is processed and analyzed using a simple statistical test. The results of the study show that the use of reading aloud methods can improve students' ability to read texts in grade III SDN. No. 028/XI Tanjung in 2017/2018 which can be seen from the increase in learning activities and improvement in learning outcomes. Student learning activities are getting better. The average score obtained by students also increased from 56.50 (pre-action) to 65.00 (cycle I) and 74.50 (cycle II). In addition, student learning completeness also increased from $33.33 \%$ (pre-action) to $60.00 \%$ (cycle I) and $86.67 \%$ (cycle II). Thus, the reading aloud method can be used as a method to improve students' ability to read texts.
\end{abstract}

Keywords: elementary school; learning activities; learning outcomes; reading aloud; reading skills

\section{PENDAHULUAN}

Bahasa memiliki peran sentral dalam perkembangan intelektual, sosial, dan emosional peserta didik dan merupakan penunjang keberhasilan dalam mempelajari semua bidang studi. Pembelajaran bahasa diharapkan membantu peserta didik mengenal dirinya, budayanya, dan budaya orang lain, mengemukakan gagasan dan perasaan, berpartisipasi dalam masyarakat yang menggunakan bahasa tersebut, dan menemukan serta menggunakan kemampuan analitis dan imaginatif yang ada dalam dirinya.

Bahasa Insonesia merupakan salah satu mata pelajaran wajib yang dipelajari dari Sekolah Dasar sampai dengan Perguruan Tinggi. Ada banyak kemampuan berbahasa yang diajarkan melalui pembelajaran Bahasa Indonesia, salah satunya adalah kemampuan membaca. Membaca merupakan suatu proses kognitif untuk menemukan berbagai informasi yang terdapat dalam tulisan atau bacaan (Dalman, 2014) dan proses tersebut sangat penting untuk mendapatkan ilmu dan pengetahuan (Resmini dan Juanda, 2007). Membaca dapat pula dianggap sebagai suatu proses untuk memahami yang tersirat dalam yang tersurat, melihat pikiran yang terkandung di dalam katakata tertulis. Tingkat pemahaman antara makna yang hendak dikemukakan oleh penulis dan penafsiran atau interpretasi membaca turut menentukan ketepatan membaca (Cahyani dan Hodijah, 2007). Berdasarkan pemaparan tersebut, membaca (reading) merupakan kemampuan yang kompleks, karena didalamnya terkait aspek mengingat, memahami, membandingkan, menemukan menganalisis, mengorganisasikan dan akhirnya menerapkan apa yang terkandung dalam bacaan.

Kemampuan membaca merupakan kemampuan yang sangat penting bagi seorang peserta didik. Hal ini dapat terjadi karena kemampuan ini diperlukan tidak hanya untuk mata pelajaran saja tetapi juga untuk mata pelajaran lain. Hasil tes penjajakan menunjukkan bahwa hasil belajar siswa termasuk dalam kategori rendah. Nilai yang diperoleh siswa berada pada rentang 45,00-
70,00 dengan nilai rata-rata sebesar 56,50 . Siswa yang memenuhi Kriteria Ketuntasan Minimum (KKM) kompetensi dasar berjumlah lima orang siswa dari jumlah total siswa sebanyak 15 siswa (persentase ketuntasan belajar siswa sebanyak 33,33\%). Hasil pengamatan menunjukkan bahwa rendahnya hasil belajar ini disebabkan oleh rendahnya kemampuan siswa dalam membaca teks dan juga sebagai akibat dari penggunaan metode yang kurang tepat. Dalam pembelajaran Bahasa Indonesia di kelas III SDN. No. 028/XI Tanjung tahun pelajaran 2017/2018, guru masih menggunakan metode ceramah yang disertai tanya jawab dan belum menerapkan metode reading aloud; pelaksanaan pembelajaran masih berpusat pada guru dan cenderung kurang melibatkan siswa secara aktif.

Permasalahan tersebut mendorong guru untuk menemukan solusi agar tujuan dari pembelajaran Bahasa Indonesia dapat tercapai. Hasil kajian literature menunjukkan bahwa cara yang dapat digunakan untuk meningkatkan kemampuan siswa dalam membaca teks adalah metode reading aloud. Hernawan (2012) mengemukakan bahwa penerapan model reading aloud dapat meningkatkan kemampuan membaca pada siswa kelas V SDN Cakraningratan No. 32 Kecamatan Laweyan Surakarta Tahun Pelajaran 2011/2012. Rochsotun (2015) juga menemukan Strategi Reading aloud dapat meningkat hasil belajar Bahasa Indonesia materi membaca dongeng di Kelas III MI Al-Hidayah Cepoko Gunung Pati Semarang Tahun Pelajaran 2015/2016. Hartono (2016) juga menemukan hasil yang sama bahwa metode reading aloud dapat meningkatkan kemampuan membaca pada siswa kelas tiga sekolah dasar. Implementasi metode reading aloud dalam pembelajaran juga dapat meningkatkan kemampuan membaca permulaan pada siswa kelas 2 SD (Litri, 2016). Dengan demikian, metode reading aloud dinilai mampu untuk meningkatkan kemampuan membaca siswa. Metode reading aloud merupakan metode yang berperan penting dalam meningkatkan kemampuan membaca siswa. Metode reading aloud juga membantu 
siswa dalam memahami isi bacaan (Besan, 2010; Rukoyah, 2014).

\section{METODE PENELITIAN}

Penelitian ini merupakan penelitian tindakan kelas. Penelitian dilakukan di SDN. No. 028/XI Tanjung, Kecamatan Hamparan Rawang, Kota Sungai Penuh, Provinsi Jambi. Kegiatan penelitian terdiri atas penyusunan proposal penelitian, pengumpulan data, pengolahan data, analisis data, dan penyusunan laporan. Penelitian dilakukan sejak bulan Juli sampai dengan bulan November tahun 2017.

Subjek dalam penelitian ini adalah siswa kelas III semester ganjil tahun pelajaran 2017/2018 di SDN. No. 028/XI Tanjung, Kecamatan Hamparan Rawang, Kota Sungai Penuh, Provinsi Jambi. Jumlah subjek yang terlibat dalam penelitian ini adalah 15 orang siswa. Objek dalam penelitian ini adalah peningkatan kemampuan membaca siswa kelas III SDN. No. 028/XI Tanjung pada mata pelajaran Bahasa Indonesia.

Data yang dikumpulkan dalam penelitian tindakan kelas ini adalah hasil belajar dan aktivitas belajar siswa pada mata pelajaran Bahasa Indonesia. Aktivitas belajar diukur dengan evaluasi belajar jenis nontes yaitu pengamatan atau observasi. Observasi merupakan cara untuk menghimpun data atau bahan-bahan keterangan yang dilakukan dengan mengadakan pengamatan dan pencatatan secara sistematis terhadap fenomenafenomena yang sedang dijadikan sasaran pengamatan. Dalam penelitian ini, observasi dilakukan untuk mengamati tingkah laku siswa selama proses pembelajaran berlangsung. Observasi dilakukan untuk mengetahui keaktifan siswa dalam melakukan skenario pembelajaran. Hasil observasi digunakan untuk mengetahui proses pembelajaran dan untuk memperbaiki kualitas pembelajaran. Data hasil belajar diperoleh melalui tes. Tes merupakan cara untuk melakukan proses penilaian dalam bentuk tugas atau serangkaian tugas yang harus dikerjakan siswa atau sekelompok siswa sehingga menghasilkan suatu nilai yang menggambarkan prestasi siswa. Dalam penelitian ini, tes bertujuan untuk mengukur hasil belajar siswa dengan cara guru memberikan pertanyaan-pertanyaan yang harus dijawab atau perintah-perintah yang harus dijalankan oleh siswa pada mata pelajaran Bahasa Indonesia. Setelah itu, guru memberikan penilaian terhadap hasil tes yang diperoleh siswa dengan cara menghitung nilai rata-rata kelas dan juga persentase ketuntasan belajar.

Penelitian tindakan kelas ini dilaksanakan dalam dua siklus yaitu siklus I dan siklus II. Setiap siklus dilakukan sebanyak dua kali pertemuan. Masing-masing siklus terdiri atas empat kegiatan, yaitu perencanaan, pelaksanakan, pengamatan, dan refleksi.

Data yang dikumpulkan diolah dan dianalisis untuk mengetahui efektifitas dan tingkat keberhasilan suatu tindakan dengan menggunakan uji statistik sederhana. Uji statistik yang digunakan adalah penghitungan nilai rata-rata hasil belajar siswa. Selanjutnya, nilai rata-rata dan persentase ketuntasan belajar siswa yang diperoleh dianalisis untuk mengetahui apakah tindakan yang diberikan berhasil atau tidak. Analisis dilakukan dengan cara membandingkan nilai rata-rata dan ketuntasan belajar yang diperoleh siswa sebelum dan sesudah tindakan. Indikator keberhasilan dari penelitian tindakan kelas ini adalah peningkatan kemampuan membaca siswa kelas III SDN. No. 028/XI Tanjung pada mata pelajaran Bahasa Indonesia. Peningkatan kemampuan membaca dilihat dari peningkatan aktivitas dan hasil belajar mengacu pada Kriteria Ketuntasan Minimum (KKM) kompetensi dasar mata pelajaran Bahasa Indonesia yang telah ditentukan oleh sekolah di awal tahun pelajaran 2017/2018 yaitu sebesar 60,00.

\section{HASIL DAN PEMBAHASAN Pratindakan}

Sebelum memberikan tindakan, guru mengadakan tes penjajakan terlebih dahulu pada siswa. Hasil belajar siswa berdasarkan tes penjajakan yang telah dilakukan disajikan pada Tabel 1. Hasil penelitian menunjukkan bahwa nilai terendah yang diperoleh siswa adalah 45,00 , sedangkan nilai tertinggi yang diperoleh siswa adalah sebesar 70,00 dengan nilai rata-rata sebesar 56,50. Nilai rata-rata ini masih termasuk dalam kategori rendah. Siswa yang mendapatkan nilai lebih besar dari KKM Kompetensi Dasar berjumlah 5 orang dengan persentase ketuntasan belajar siswa sebesar $33,33 \%$. Dengan demikian, perlu adanya pemberian tindakan untuk mengatasi masalah tersebut.

Tabel 1. Hasil tes penjajakan

\begin{tabular}{clccl}
\hline No & \multicolumn{1}{c}{ Nama Siswa } & KKM & Nilai & Keterangan \\
\hline 1 & Ade Rizki Hidayat & 60,00 & 55,00 & Tidak Tuntas \\
2 & Afifah Aprilia & 60,00 & 60,00 & Tuntas \\
3 & Bebi Siputra & 60,00 & 45,00 & Tidak Tuntas \\
4 & Fazlan Hadi Ambiya & 60,00 & 70,00 & Tuntas \\
5 & Indah Amelisa & 60,00 & 50,00 & Tidak Tuntas \\
6 & Laura Anggraini & 60,00 & 70,00 & Tuntas \\
7 & Mhd. Naufal Al Azizi Y & 60,00 & 50,00 & Tidak Tuntas \\
8 & Nofiza Pitri & 60,00 & 55,00 & Tidak Tuntas \\
9 & Nur Safika & 60,00 & 60,00 & Tuntas \\
10 & Padril Ahmad & 60,00 & 50,00 & Tidak Tuntas \\
11 & Sarah Aryanti & 60,00 & 50,00 & Tidak Tuntas \\
12 & Tio Zomi Setiawan & 60,00 & 55,00 & Tidak Tuntas \\
13 & Wira Pratama & 60,00 & 60,00 & Tuntas \\
14 & Venti Meisya Utami & 60,00 & 45,00 & Tidak Tuntas \\
15 & Zafiq Sastra Dinata & 60,00 & 40,00 & Tidak Tuntas \\
& Nilai Tertinggi & & 70,00 & \\
& Nilai Terendah & & 45,00 & \\
& Nilai Rata-Rata & & 56,50 & \\
& Ketuntasan Belajar (\%) & & 33,33 & \\
\hline
\end{tabular}

\section{Siklus I}

Kegiatan penelitian pada siklus I dilaksanakan pada hari Senin, 31 Juli 2017 (Pertemuan ke-1 Siklus I), hari Rabu, 2 Agustus 2017 (Pertemuan ke-2 Siklus I), dan hari Senin, 7 Agustus 2017 (Evaluasi Hasil Belajar Siklus I). Kegiatan penelitian pada siklus I terdiri atas perencanaan, pelaksanaan, pengamatan, dan refleksi.

Kegiatan perencanaan terdiri atas: Menetapkan materi yang akan diajarkan; Menyusun Rencana Pelaksanaan Pembelajaran (RPP); Menyusun skenario pembelajaran; Menyiapkan alat dan bahan yang dibutuhkan; dan Menyiapkan alat evaluasi.

Kegiatan pelaksanaan tindakan terdiri atas: Guru mengucapkan salam dan menanyakan keadaan siswa; Guru memeriksa kehadiran siswa secara klasikal; Guru menyampaikan tujuan pembelajaran; Guru menyampaikan skenario pembelajaran yang akan 
dilaksanakan; Guru memilih teks untuk dibaca oleh siswa dengan keras; Guru mengundang beberapa orang siswa untuk membacakan teks; Guru bertanya kepada siswa mengenai isi teks yang dibaca; Guru memberikan kesempatan kepada siswa untuk memberikan tanggapan; Guru bersama siswa membuat kesimpulan pembelajaran; Guru menyampaikan gambaran materi pelajaran selanjutnya; Guru menyampaikan pesan moral.

Kegiatan pengamatan terdiri atas: mengamati aktivitas siswa selama kegiatan pembelajaran dan mencatat kejadian-kejadian yang terjadi selama pelaksanaan kegiatan pembelajaran. Hasil pengamatan aktivitas belajar siswa pada Siklus I disajikan pada Tabel 2.

Tabel 2. Hasil pengamatan aktivitas belajar siswa pada akhir Siklus I

\begin{tabular}{|c|c|c|c|}
\hline No & Kriteria & Jumlah & Persen \\
\hline 1 & Siswa mendengarkan penjelasan guru & 12 & $80,0 \%$ \\
\hline 2 & $\begin{array}{l}\text { Siswa memperhatikan ketika siswa lain } \\
\text { membaca teks di depan kelas }\end{array}$ & 12 & $80,0 \%$ \\
\hline 3 & $\begin{array}{l}\text { Siswa mengajukan pertanyaan pada } \\
\text { guru }\end{array}$ & 9 & $60,0 \%$ \\
\hline 4 & $\begin{array}{l}\text { Siswa memberikan tanggapan atas } \\
\text { pertanyaan guru }\end{array}$ & 9 & $60,0 \%$ \\
\hline 5 & $\begin{array}{l}\text { Siswa membaca teks dengan lafal dan } \\
\text { intonasi yang tepat }\end{array}$ & 9 & $60,0 \%$ \\
\hline 6 & $\begin{array}{l}\text { Siswa menuliskan jawaban pertanyaan } \\
\text { yang berkaitan dengan isi teks yang } \\
\text { telah dibaca }\end{array}$ & 9 & $60,0 \%$ \\
\hline
\end{tabular}

Selain hasil pengamatan aktivitas belajar siswa, guru juga mengukur hasil belajar siswa melalui tes. Hasil evaluasi hasil belajar siswa pada Siklus I disajikan pada Tabel 3.

Tabel 3. Hasil penelitian pada Siklus I

\begin{tabular}{clccl}
\hline No & \multicolumn{1}{c}{ Nama Siswa } & KKM & Nilai & Keterangan \\
\hline 1 & Ade Rizki Hidayat & 60,00 & 65,00 & Tuntas \\
2 & Afifah Aprilia & 60,00 & 70,00 & Tuntas \\
3 & Bebi Siputra & 60,00 & 50,00 & Tidak Tuntas \\
4 & Fazlan Hadi Ambiya & 60,00 & 80,00 & Tuntas \\
5 & Indah Amelisa & 60,00 & 55,00 & Tidak Tuntas \\
6 & Laura Anggraini & 60,00 & 75,00 & Tuntas \\
7 & Mhd. Naufal Al Azizi Y & 60,00 & 55,00 & Tidak Tuntas \\
8 & Nofiza Pitri & 60,00 & 65,00 & Tuntas \\
9 & Nur Safika & 60,00 & 75,00 & Tuntas \\
10 & Padril Ahmad & 60,00 & 60,00 & Tuntas \\
11 & Sarah Aryanti & 60,00 & 55,00 & Tidak Tuntas \\
12 & Tio Zomi Setiawan & 60,00 & 65,00 & Tuntas \\
13 & Wira Pratama & 60,00 & 65,00 & Tuntas \\
14 & Venti Meisya Utami & 60,00 & 50,00 & Tidak Tuntas \\
15 & Zafiq Sastra Dinata & 60,00 & 45,00 & Tidak Tuntas \\
& Nilai Tertinggi & & 80,00 & \\
& Nilai Terendah & & 50,00 & \\
& Nilai Rata-Rata & & 65,00 & \\
& Ketuntasan Belajar & & $60,00 \%$ & \\
\hline
\end{tabular}

Hasil penelitian yang disajikan pada Tabel 3 menunjukkan bahwa nilai terendah yang diperoleh siswa adalah 50,00, sedangkan nilai tertinggi yang diperoleh siswa adalah sebesar 80,00 dengan nilai rata-rata sebesar 65,00 . Nilai rata-rata yang diperoleh siswa pada siklus I setelah diberikan tindakan berupa penggunaan metode reading aloud meningkat apabila dibandingkan dengan nilai rata-rata yang diperoleh siswa pada tes penjajakan. Saat tes penjajakan, nilai rata-rata yang diperoleh siswa adalah 56,50. Nilai rata-rata ini meningkat sekitar 8,50 point menjadi 65,00 pada siklus I. Selain nilai rata-rata, persentase ketuntasan belajar siswa juga meningkat dari 33.33 persen pada saat tes penjajakan menjadi 60,00 persen pada siklus I. Dengan demikian, penggunaan metode reading aloud telah menunjukkan kemajuannya dalam meningkatkan hasil belajar dan aktivitas belajar siswa pada mata pelajaran Bahasa Indonesia. Oleh karenanya, guru perlu melanjutkan penggunaan metode ini ke siklus selanjutnya.

\section{Refleksi} berikut:

Refleksi dari hasil penelitian adalah sebagai

1. Guru perlu memperbaiki perangkat pembelajaran berdasarkan hasil evaluasi siklus I.

2. Guru memberikan motivasi kepada siswa untuk aktif bertanya dan memberikan tanggapan selama kegiatan pembelajaran.

3. Guru mendampingi siswa ketika membaca teks agar pelafalan dan intonasi yang digunakan tepat

4. Merumuskan tindakan siklus II berdasarkan temuan pada siklus I.

\section{Siklus II}

Kegiatan penelitian pada siklus II dilaksanakan pada hari Senin, 21 Agustus 2017 (Pertemuan ke-1 Siklus I), hari Rabu, 23 Agustus 2017 (Pertemuan ke-2 Siklus I), dan hari Senin, 28 Agustus 2017 (Evaluasi Hasil Belajar Siklus II). Kegiatan penelitian pada siklus II terdiri atas perencanaan, pelaksanaan, pengamatan, dan refleksi.

Kegiatan perencanaan terdiri atas: Menetapkan materi yang akan diajarkan; menyusun Rencana Pelaksanaan Pembelajaran (RPP); menyusun skenario pembelajaran; menyiapkan alat dan bahan yang dibutuhkan; dan menyiapkan alat evaluasi.

Kegiatan pelaksanaan tindakan terdiri atas: Guru mengucapkan salam dan menanyakan keadaan siswa; Guru memeriksa kehadiran siswa secara klasikal; Guru menyampaikan tujuan pembelajaran; Guru menyampaikan skenario pembelajaran yang akan dilaksanakan; Guru memilih teks untuk dibaca oleh siswa dengan keras; Guru mengundang beberapa orang siswa untuk membacakan teks; Guru bertanya kepada siswa mengenai isi teks yang dibaca; Guru memberikan kesempatan kepada siswa untuk memberikan tanggapan; Guru bersama siswa membuat kesimpulan pembelajaran; Guru menyampaikan gambaran materi pelajaran selanjutnya; Guru menyampaikan pesan moral.

Kegiatan pengamatan terdiri atas: mengamati aktivitas siswa selama kegiatan pembelajaran dan mencatat kejadian-kejadian yang terjadi selama pelaksanaan kegiatan pembelajaran. Hasil pengamatan aktivitas belajar siswa pada Siklus II disajikan pada Tabel 4 
Tabel 4. Hasil pengamatan aktivitas belajar siswa pada akhir Siklus II

\begin{tabular}{|c|c|c|c|}
\hline No & Kriteria & Jumlah & Persentase \\
\hline 1 & $\begin{array}{l}\text { Siswa mendengarkan penjelasan } \\
\text { guru }\end{array}$ & 15 & $100,00 \%$ \\
\hline 2 & $\begin{array}{l}\text { Siswa memperhatikan ketika siswa } \\
\text { lain membaca teks di depan kelas }\end{array}$ & 15 & $100,00 \%$ \\
\hline 3 & $\begin{array}{l}\text { Siswa mengajukan pertanyaan pada } \\
\text { guru }\end{array}$ & 13 & $86,67 \%$ \\
\hline 4 & $\begin{array}{l}\text { Siswa memberikan tanggapan atas } \\
\text { pertanyaan guru }\end{array}$ & 13 & $86,67 \%$ \\
\hline 5 & $\begin{array}{l}\text { Siswa membaca teks dengan lafal } \\
\text { dan intonasi yang tepat } \\
\text { Siswa menuliskan jawaban }\end{array}$ & 13 & $86,67 \%$ \\
\hline 6 & $\begin{array}{l}\text { pertanyaan yang berkaitan dengan } \\
\text { isi teks yang telah dibaca }\end{array}$ & 13 & $86,67 \%$ \\
\hline
\end{tabular}

Selain hasil pengamatan aktivitas belajar siswa, guru juga mengukur hasil belajar siswa melalui tes. Hasil evaluasi hasil belajar siswa pada Siklus II disajikan pada Tabel 5. Hasil penelitian yang disajikan pada Tabel 5 menunjukkan bahwa nilai terendah yang diperoleh siswa adalah 55,00, sedangkan nilai tertinggi yang diperoleh siswa adalah sebesar 90,00 dengan nilai rata-rata sebesar 74,50. Nilai rata-rata yang diperoleh siswa pada siklus II meningkat apabila dibandingkan dengan nilai rata-rata yang diperoleh siswa pada Siklus I. Nilai ratarata yang diperoleh siswa saat siklus I adalah 65,00. Nilai rata-rata ini meningkat sekitar 9,50 point menjadi 74,50 . Selain nilai rata-rata, persentase ketuntasan belajar siswa juga meningkat dari 60,00 persen pada saat Siklus I menjadi 86,67 persen pada siklus II. Dengan demikian, penggunaan metode reading aloud mampu meningkatkan aktivitas dan hasil belajar siswa kelas III SDN. No. 028/XI Tanjung pada mata pelajaran Bahasa Indonesia.

Tabel 5. Hasil penelitian pada Siklus II

\begin{tabular}{clccl}
\hline No & \multicolumn{1}{c}{ Nama Siswa } & KKM & Nilai & Keterangan \\
\hline 1 & Ade Rizki Hidayat & 60,00 & 70,00 & Tuntas \\
2 & Afifah Aprilia & 60,00 & 85,00 & Tuntas \\
3 & Bebi Siputra & 60,00 & 55,00 & Tidak Tuntas \\
4 & Fazlan Hadi Ambiya & 60,00 & 90,00 & Tuntas \\
5 & Indah Amelisa & 60,00 & 65,00 & Tuntas \\
6 & Laura Anggraini & 60,00 & 90,00 & Tuntas \\
7 & Mhd. Naufal Al Azizi Y & 60,00 & 60,00 & Tuntas \\
8 & Nofiza Pitri & 60,00 & 75,00 & Tuntas \\
9 & Nur Safika & 60,00 & 85,00 & Tuntas \\
10 & Padril Ahmad & 60,00 & 70,00 & Tuntas \\
11 & Sarah Aryanti & 60,00 & 70,00 & Tuntas \\
12 & Tio Zomi Setiawan & 60,00 & 75,00 & Tuntas \\
13 & Wira Pratama & 60,00 & 75,00 & Tuntas \\
14 & Venti Meisya Utami & 60,00 & 60,00 & Tuntas \\
15 & Zafiq Sastra Dinata & 60,00 & 55,00 & Tidak Tuntas \\
& Nilai Tertinggi & & 90,00 & \\
& Nilai Terendah & & 55,00 & \\
& Nilai Rata-Rata & & 84,50 & \\
& Ketuntasan Belajar & & & \\
\hline
\end{tabular}

\section{Refleksi}

berikut:

Refleksi dari hasil penelitian adalah sebagai

1. Metode reading aloud telah membawa perubahan yang baik pada aktivitas siswa maupun dalam hal hasil belajar siswa. Dengan demikian, metode ini dapat menjadi alternatif dalam kegiatan pembelajaran Bahasa Indonesia.

2. Hasil penelitian menunjukkan bahwa masih terdapat dua orang siswa yang mengalami kesulitan dalam mengajukan pertanyaan, memberikan tanggapan, membaca teks dengan lafal dan intonasi yang tepat, serta menuliskan jawaban pertanyaan tentang isi teks dengan benar. Dengan demikian, guru perlu mendorong dan memberikan motivasi pada siswa untuk meningkatkan kepercayaan diri siswa untuk mampu berbicara di kelas. Selain itu, guru juga sebaiknya mendampingi siswa dalam menjawab soal latihan.

3. Guru juga perlu melakukan evaluasi diri untuk menemukan masalah pembelajaran yang berasal dari faktor guru. Guru diharapkan juga dapat mengurangi masalah yang disebabkan dari guru sendiri. Hal ini perlu dilakukan untuk meningkatkan kualitas pembelajaran.

4. Hasil penelitian ini menjadi acuan dalam menyusun perangkat pembelajaran untuk materi selanjutnya.

\section{Analisis Peningkatan Hasil Belajar Siswa}

Dalman (2014) mendefinisikan metode membaca nyaring adalah suatu aktivitas atau kegiatan yang merupakan alat bagi pendidik, peserta didik ataupun pembaca bersama-sama dengan orang lain atau pendengar untuk menangkap atau memahami informasi, pikiran, dan perasaan seorang pengarang. Metode membaca nyaring adalah kegiatan membaca dengan menyuarakan tulisan yang dibacanya dengan ucapan dan intonasi yang tepat agar pendengar dan pembaca menangkap informasi yang disampaikan oleh pembaca (Saddhono dan Slamet, 2012). Metode membaca nyaring atau membaca bersuara keras merupakan kegiatan yang dilakukan untuk meningkatkan kemampuan membaca dan menyimak. Dengan membaca nyaring, seluruh peserta didik yang ada di dalam kelas akan memperhatikan bahan bacaan sehingga ketika temannya membaca akan tahu kesalahannya (Resmini dan Juanda, 2007).

Metode membaca nyaring atau membaca bersuara merupakan kelanjutan dari membaca permulaan. Pada membaca permulaan tekanan ada pada kelancaran dan ketepatan penyuaraan huruf. Pada membaca nyaring atau membaca bersuara difokuskan pada tekanan kata, lagu kalimat, jeda, dan menguasai tanda baca. Metode membaca nyaring adalah kegiatan yang paling penting dalam membangun pengetahuan dan keterampilan berbahasa peserta didik (Rahim, 2011). Karena dalam membaca nyaring merupakan suatu aktivitas yang menuntut aneka keterampilan. Berdasarkan pemaparan tersebut, metode membaca nyaring dapat diartikan sebagai jenis metode membaca dengan menyuarakan bacaan dengan suara yang keras dan lantang.

Metode membaca nyaring sangat penting karena membaca nyaring bukan sekadar melafalkan atau menyuarakan huruf, akan tetapi dalam membaca nyaring juga memerlukan keterampilan khusus agar proses membaca dapat berjalan lancar. Tujuan metode membaca nyaring yaitu agar seseorang mampu mempergunakan ucapan yang tepat, membaca dengan jelas, dan tidak terbata-bata, membaca dengan tidak terus menerus melihat pada bahan bacaan, membaca dengan menggunakan intonasi dan lagu yang tepat dan jelas (Dalman, 2014). 
Hasil penelitian menunjukkan bahwa aktivitas dan hasil belajar siswa setelah diberikan tindakan berupa metode reading aloud meningkat dibandingkan dengan aktivitas dan hasil belajar siswa sebelum diberikan tindakan. Nilai rata-rata yang diperoleh siswa sebelum diberikan tindakan adalah 56,50. Nilai rata-rata ini meningkat menjadi 65,00 pada siklus I dan kembali meningkat menjadi 74,50 pada siklus II. Selain itu, peningkatan juga terjadi pada persentase ketuntasan belajar siswa. Sebelum diberikan tindakan, ketuntasan belajar siswa adalah sebesar $33,33 \%$. Persentase ini meningkat menjadi $60,00 \%$ pada Siklus I dan kembali meningkat menjadi $86,67 \%$ pada Siklus II. Rekapitulasi hasil belajar siswa pada saat pratindakan, siklus I, dan siklus II disajikan pada Gambar 1.

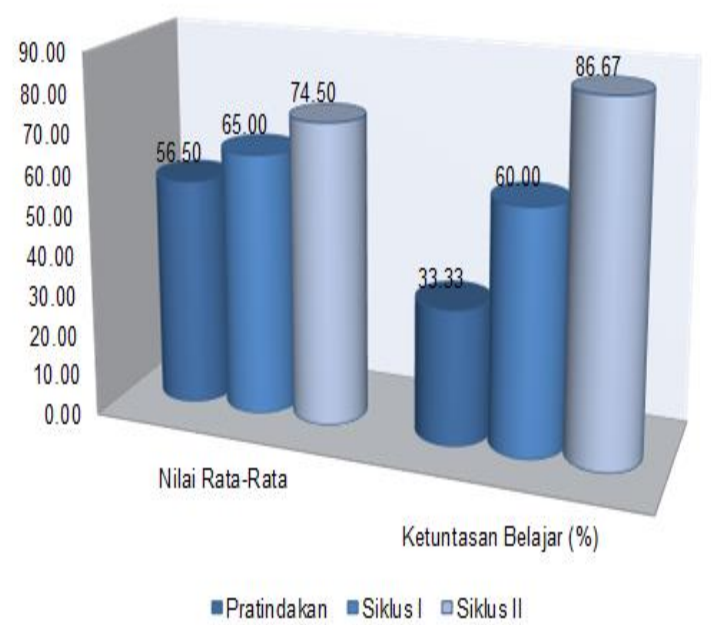

Gambar 1. Rekapitulasi hasil belajar siswa pada saat pratindakan, siklus I, dan siklus II

Hasil penelitian menunjukkan bahwa terjadi peningkatan hasil belajar siswa dari sebelum dilaksanakan tindakan sampai dengan setelah dilaksanakan tindakan (siklus I dan siklus II). Berdasarkan hasil penelitian, dapat disimpulkan bahwa penggunaan metode reading aloud dapat meningkatkan kemampuan siswa dalam membaca teks di kelas III SDN. No. 028/XI Tanjung tahun 2017/2018. Hasil ini mendukung temuan sebelumnya, seperti Hernawan (2012), Rochsotun (2015), Hartono (2016), dan Litri (2016). Hernawan (2012) mengemukakan bahwa penerapan model reading aloud dapat meningkatkan kemampuan membaca pada siswa kelas $\mathrm{V}$ SDN Cakraningratan No. 32 Kecamatan Laweyan Surakarta Tahun Pelajaran 2011/2012. Rochsotun (2015) juga menemukan Strategi Reading aloud dapat meningkat hasil belajar Bahasa Indonesia materi membaca dongeng di Kelas III MI Al-Hidayah Cepoko Gunung Pati Semarang Tahun Pelajaran 2015/2016. Hartono (2016) juga menemukan hasil yang sama bahwa metode reading aloud dapat meningkatkan kemampuan membaca pada siswa kelas tiga sekolah dasar. Implementasi metode reading aloud dalam pembelajaran juga dapat meningkatkan kemampuan membaca permulaan pada siswa kelas 2 SD (Litri, 2016).

\section{SIMPULAN}

Penggunaan metode reading aloud dapat meningkatkan kemampuan siswa dalam membaca teks di kelas III SDN. No. 028/XI Tanjung tahun 2017/2018. Peningkatan ini dapat dilihat dari peningkatan aktivitas belajar dan peningkatan hasil belajar. Aktivitas belajar siswa semakin baik. Nilai rata-rata yang diperoleh siswa juga meningkat dari 56,50 (pratindakan) menjadi 65,00 (siklus I) dan kembali meningkat menjadi 74,50 (siklus II). Selain itu, peningkatan juga terjadi pada persentase ketuntasan belajar siswa. Ketuntasan belajar meningkat dari $33,33 \%$ (pratindakan) menjadi $60,00 \%$ (siklus I) dan kembali meningkat menjadi $86,67 \%$ (siklus II).

Berdasarkan temuan penelitian, pendidik diharapkan dapat menggunakan metode reading aloud sebagai alternatif dalam meningkatkan aktivitas dan hasil belajar siswa pada mata pelajaran Bahasa Indonesia. Pendidik diharapkan juga untuk menambah pengetahuannya melalui kegiatan pelatihan. Pendidik diharapkan juga dapat menggunakan model, pendekatan, strategi, metode, dan teknik pembelajaran yang variatif dan inovatif. Penelitian ini juga menyarankan kepada pendidik untuk memecahkan permasalahan pembelajaran di kelas melalui kegiatan Penelitian Tindakan Kelas.

\section{DAFTAR PUSTAKA}

Besan, A. (2010). Peningkatan Kemampuan Membaca Pemahaman dengan Strategi Pemodelan pada Siswa Kelas IV SD Negeri Sumbersari III Malang (Tesis). Malang: Program Pascasarjana, Universitas Malang.

Cahyani, I., \& Hodijah. 2007. Kemampuan Berbahasa Indonesia di SD. Bandung: UPI Press.

Dalman. (2014). Keterampilan Membaca. Jakarta: Rajawali Pers.

Hartono, M. N. (2016). Metode read aloud untuk meningkatkan kemampuan membaca pemahaman pada siswa kelas tiga sekolah dasar [tesis]. Semarang: Magister Profesi Psikologi Program Pasca Sarjana, Universitas Katolik Soegijapranata Semarang.

Hernawan, R. A. (2012). Penerapan model reading aloud untuk meningkatkan kemampuan membaca pada siswa kelas V SDN Cakraningratan No. 32 Kecamatan Laweyan Surakarta Tahun Pelajaran 2011/2012 [Skripsi]. Surakarta: Program Studi PGSD Fakultas Keguruan dan IImu Pendidikan, Universitas Muhammadiyah Surakarta.

Litri, H. J. (2016). Implementasi metode reading aloud dalam pembelajaran membaca permulaan pada siswa kelas 2 SD. Jurnal Pendidikan Guru Sekolah Dasar, 31, halaman 2946-2957.

Rochsotun, S. (2015). Peningkatan Hasil Belajar Bahasa Indonesia Materi Membaca Dongeng menggunakan Strategi Reading aloud di Kelas III MI Al-Hidayah Cepoko Gunung Pati Semarang Tahun Pelajaran 2015/2016 [Skripsi]. Semarang: Fakultas IImu Tarbiyah dan Keguruan, Universitas Islam Negeri Walisongo.

Rahim, F. (2011). Pengajaran Membaca di Sekolah Dasar. Jakarta: PT Bumi Aksara. 
Resmini, N., \& Juanda, D. (2007). Pendidikan Bahasa dan Sastra di Kelas Tinggi. Bandung: UPI Press.

Rukoyah, S. (2014). Pengaruh Metode Reading aloud (Membaca Nyaring) Terhadap Pemahaman Bacaan Siswa Kelas II MI Nurul Huda Curug Wetan Tangerang Tahun Pelajaran 2013/2014 [Skripsi]. Jakarta: Jurusan Pendidikan Guru Madrasah Ibtidaiyah, Fakultas IImu Tarbiyah dan Keguruan, Universitas Islam Negeri Syarif Hidayatullah Jakarta.

Saddhono, K., \& Slamet, S. Y. (2012) Meningkatkan Keterampilan Berbahasa Indonesia. Bandung: Karya Putra Darwati. 